\title{
THE ESTIMATION ACCURACY OF LIVE WEIGHT FROM METRIC BODY MEASUREMENTS IN ONGOLE GRADE COWS
}

\author{
U. Paputungan ${ }^{1}$, L. Hakim ${ }^{2}$, G. Ciptadi ${ }^{2}$ and H.F.N. Lapian ${ }^{1}$ \\ ${ }^{1}$ Faculty of Animal Science, Sam Ratulangi University, \\ Bahu Campus, Manado 95115 - Indonesia \\ ${ }^{2}$ Faculty of Animal Husbandry, Brawijaya University, \\ $\mathrm{Jl}$. Veteran, Malang 65145 - Indonesia \\ Corresponding E-mail: umarfapet@yahoo.com
}

Received May 30, 2013; Accepted August 22, 2013

\begin{abstract}
ABSTRAK
Kajian ini dilaksanakan di Kabupaten Minahasa-Propinsi Sulawesi Utara untuk mengestimasi berat hidup sapi Peranakan Ongole (PO) dengan menggunakan ukuran lingkar dada dan panjang badan induk. Data berat hidup [(live weight) LW], panjang badan [(body length) BL], dan lingkar dada [(chest girth) $\mathrm{CG}$ ] diambil dari sapi betina PO induk $(\mathrm{n}=363)$ yang dipelihara secara tradisional oleh para petani. Analisis regresi dipakai untuk menduga LW dari semua ukuran linear tubuh. Data dikelompokkan berdasarkan umur ternak. Umur ternak terdiri dari lima kelompok dengan kelompok umur pertama pada dua setengah tahun sampai kelompok umur ke lima pada umur tujuh setengah tahun. Hasil penelitian menunjukkan bahwa umur mempengaruhi ukuran-ukuran tubuh secara signifikan $(\mathrm{P}<0,05)$. Korelasi antara semua pasangan hasil-hasil pengukuran ternak adalah sangat signifikan $(\mathrm{P}<0,001)$ pada semua kelompok umur. Analisis regresi berganda menunjukkan bahwa berat hidup dapat diprediksi dengan tepat dari lingkar dada dan panjang badan $\left(\mathrm{R}^{2}=0,97\right)$. Model regresi berganda yang dapat disarankan memrediksi berat hidup sapi berdasarkan kedua variabel tersebut dengan kelompok umur berkisar dari umur 2,5 sampai $\geq 7,5$ tahun adalah: Berat hidup $[(\mathrm{LW}) \mathrm{kg}]=-806,410+4,79835 \mathrm{CG}(\mathrm{cm})+2,83500$ $\mathrm{BL}(\mathrm{cm})$.
\end{abstract}

Kata kunci: Sapi betina induk PO, estimasi berat hidup, ukuran linear tubuh

\begin{abstract}
A study was conducted to estimate live weight in Ongole grade cow using its chest girth and body length in North Sulawesi province. Data on animal live weight (LW), body length (BL) and chest girth (CG) were collected from all cows $(n=363)$ kept by traditional household farmers. Regression analysis was carried out to estimate LW from all linear body measurements. Data were classified based on age of animals consisted of five groups with the first age group of two and half years old, to the fifth age group of seven and half years old. The results showed that age significantly $(\mathrm{P}<0.05)$ influenced all body measurements. Correlations between all pairs of measurements were highly significant $(\mathrm{P}<0.001)$ for all age groups. Regression analysis showed that live weight could be predicted accurately from chest girth and body length $\left(\mathrm{R}^{2}=0.97\right)$. Multiple regression model can be recommended to predict live weight of Ongole grade cows based on those variables with their age groups ranging from 2.5 to $\geq 7.5$ years old as follows: Live weight $(\mathrm{kg})=-806.410+4.79835 \mathrm{CG}(\mathrm{cm})+2.83500 \mathrm{BL}(\mathrm{cm})$.
\end{abstract}

Keywords: Ongole crossbred cows, live weight estimation, body linear measurements.

\section{INTRODUCTION}

Most Ongole crossbred cattle in rural areas of Indonesia were owned by rural households and farmers. Often, the marketing of animals was based on visual assesment, while drugs were administrated mostly by estimation. Regularly, the right use of live weight criteria in feeding, marketing and drug administration required sophisticated facilities such as weighing scales (monitor digital electrical scale), which was expensive and not readily affordable by many rural households. Positive correlation between the live weight and most of the body measurements 
was found in several scientific reports (Afolayan et al., 2006; Bene et al., 2007; Ozkaya and Bozkurt, 2009; Sawanon et al., 2011; Udeh et al., 2011). This fact repeatedly calls the attention to the important of taking cattle body measurement, and offers opportunity for estimating parameters in relation to the various body measurements.

Several scientific reports suggested that body measurements have been of recurring interest in beef cattle and small ruminant selection and breeding programs (Bene et al., 2007; Fajemilehin and Salako, 2008; Jimmy et al., 2010). Ulutas et al. (2001) reported that body weight of animals was an important factor associated with several management practices including selection for slaughter, breeding of ideal weight cows mated with higher bull weight, determining feeding levels and also it is good indicator of animal condition. Beef cattle production of local household farmers was difficult to be practically predicted due to limited availability of animal weighing scale machine on the field.

Animal growth in developed farm system was generally measured by average daily gain, and body size was generally detected by increase of chest girth and body length (Willeke and Dursch, 2002; Bozkurt, 2006; Ozkaya and Bozkurt, 2008). Dimensions of animal chest girth and animal body length in $\mathrm{cm}$ unit were very simple and easily measured for estimating animal live weight although it was unlikely to be more accurate than direct measurement of live weight by scale due to errors in location reference points. Cattle body weight had positive correlation with body dimensions including body length, hip height and chest girth (Ozkaya and Bozkurt, 2009; Puspitaningrum, 2009). Ozkaya and Boskurt (2009) reported that correlation coefficient between body weight and body measurements of body length and chest girth in Holstein breed were 0.69 and 0.78, respectively. Puspitanigrum (2009) reported also that body weight was moderately correlated with chest girth and body length of 0.77 and 0.66 , respectively in Brahman grade beef cattle. These correlation values indicated relatively low accuracy for estimation of animal body weight in case of using single variable of either chest girth or body length as predictor variable (Fajemilehin and Salako, 2008; Puspitaningrum, 2009).

Animal breeding strategies of household farmers in this research location at Minahasa regency, North Sulawesi, were mated with the artificial insemination technique by the inseminator using bull sperms collected from Ongole Bull Sperm Bank Institution, located in Singosari, East Java Province. Therefore, cow populations were higher compared with bull population with ratio of about $4: 1$. The main issue of local animal breeding was selection of the ideal body weight cows mated with high bull weight by the artificial insemination. The problem was that the practical estimation accuracy of cow live weight from metric body measurements has not been exploited and applied to estimate cow body weight, mainly Ongole grade cows. In this research, cow's chest girth and body length were combined to be applied in a formula of multiple regression model. Cows household farmers used in this research were located in two villages of Tumaratas and Tonsewer, Minahasa Regency, North Sulawesi Province. The objective of this research was to determine the accuracy of cow body weight prediction from a linear metric body measurements or combination of body measurements in Ongole grade cows.

\section{MATERIALS AND METHODS}

\section{Location of Study and Experimental Animals}

Animals used in this research were Ongole grade cows with unknown composition of Ongole breed and Local Indonesian beef cattle in North Sulawesi Province. All animals used in this study were unpregnant and healthy cows at age groups ranging from two to seven and half years old and they were suckling their calves at ages ranging from one week to two months old. Animal breeding strategy of household farmers were mated with the artificial insemination technique by the inseminator using bull sperms collected from Ongole Bull Sperm Bank Institution, located in Singosari, East Java Province, Indonesia. Cows household farmers were located in two villages of Tumaratas and Tonsewer, Minahasa Regency, North Sulawesi Province. This regency is categorized as agricultural areas with altitude of $600-700 \mathrm{~m}$ above sea level. It is characterized by cool and humid climate of $25-28^{\circ} \mathrm{C}$ and $70-80$ percents, respectively.

The number of Ongole grade animals, randomly chosen in this study, were 363 grass-fed cows. Age was primarily determined by dentition with the indication as follows: cows showed unchanged milk teeth, indicating the age of less than one year old; cows showed two changed milk teeth, indicating the age of one and half to two and half years old; cows showed four changed 
milk teeth, indicating the age of two and half to three and half years old; cows showed six changed milk teeth, indicating the age of three and half to four and half years old; and cows showed eight changed milk teeth, indicating the age of above five years old. Detition indicators were verified with household farmer information and records by the inseminators. The unhealthy and pregnant cows were excluded in this study.

\section{Measured Traits}

Measurements of cow body dimensions were taken form July to August 2011 on each Ongole grade population including body length (BL), measured using a tape measure from distance between the site of pins (tuber ischii) to tail drop (tuberositas humeri), chest girth (CG), measured with a tape measure as body circumference of the chest just behind the foreleg. Animals were also weighed directly using the monitor digital electrical scale equipment tool with the maximum capacity of $2000 \mathrm{~kg}$ of the equipment tool. This equipment tool was eligibly used due to the maximum cow weight of less than $2000 \mathrm{~kg}$. The accurate weight value in kilogram and gram digital unit of cow weighed was directly read on the monitor of electrical weighing indicator connecting with the floor cable of animal scale equipment tool, where the cow was standing on.

\section{Statistical Analysis}

The data collected on each animal were analysed using the Insert Function Procedure of the related statistical category in datasheet of Microsofl Office Excel (2007) within the animal age groups. The interrelationship of body weights and body measurements were estimated by simple correlation and regression (Steel and Torrie, 1980). The fixed effect considered was age of animal. The model used was as follows:

$$
Y_{i j k}=\mu+\alpha_{i}+\sum b_{t} X_{i j k}\left(\alpha_{i}\right)+\varepsilon_{i j k}
$$

Where, Yijk was record of live weight of each animal; $\mu$ was overall mean; $\alpha i$ was the fixed effect of $i^{\text {th }}$ age of the animal, $b_{t}$ was partial regression coefficient of live weight on $\mathrm{t}^{\text {th }}$ continuous independent variable $\left(\mathrm{X}_{\mathrm{ijk}}\right)$ within the $\mathrm{i}^{\text {th }}$ age of the animal and $\varepsilon_{\mathrm{ijk}}$ was random error associated with record of each animal. Age of the animals consisted of five age groups with the first age group of two and half year old to the fifth age group of seven and half year old.

The best estimation equations for body weight from other traits (chest girth and body length) as independent variables were determined. Descriptive statistics and regression analysis of body weight on each of the independent variable were performed using the Insert Function Procedure of the related statistical category in datasheet of Microsoft Office Excel (2007) referring to multiple regression model described by Byrkit (1987). Comparisons between means were determined by Tukey test.

Correlation coefficients were also obtained from parameters. Linear regression effects of independent variables on live weight were included in the following model:

$$
Y_{i}=b_{0}+b_{1} X_{1}+b_{2} X_{2}+e_{i}
$$

Where $Y_{i}$ is the live weight observation of an $i^{\text {th }}$ animal; $b_{0}$ is the intercept; $b_{1}$ and $b_{2}$ are the regression coefficients, $X_{1}$ is the chest girth, $X_{2}$ is the body length, and $e_{1}$ is the residual error term.

\section{RESULTS AND DISCUSSION}

The least square means and standard errors from the general linear model analysis of live weight (LW) and measurements of chest girth (CG) and body length (BL) in Ongole grade cows at the various age groups are as presented in Table 1. Age was found to significantly influence $(\mathrm{P}<0.05)$ chest girth and live weight up till age groups of 5.5 to 6.5 years old, but do differ significantly $(\mathrm{P}<0.05)$ at age groups of 3.5 to 4.5 years old on trait of body length.

Table 2 presented the coefficients of correlation between trait pairs of animal live weight, chest girth and body length. The correlations between all pairs of measurements of chest girth, and live weight were highly significant $(\mathrm{P}<0.001)$ except those between pair of body length and chest girth $(\mathrm{P}>0.05)$ for all age groups.

Table 3 presented the summary of simple linear regression analysis and generating models for predicting overall traits from live weight dan animal body measurements. The analysis showed that overall cow live weight can be predicted from cow chest girth with moderate determination coefficients $\left(\mathrm{R}^{2}\right)$ ranging from 0.71 to 0.86 . Howover, the overall cow live weight could not be predicted from body length measuremen indicated by low determination coefficients $\left(\mathrm{R}^{2}\right)$ ranging from 0.05 to 0.50 . The multiple regression analysis for combination of chest girth and body length showed that overall cow live weights can be predicted accurately from 
Table 1. Least square means of Live Weight and Body Measurements in Ongole Grade Cows

\begin{tabular}{ccccc}
\hline Age $($ years $)$ & $\mathrm{N}$ & $\mathrm{CG}(\mathrm{cm})$ & $\mathrm{BL}(\mathrm{cm})$ & LW $(\mathrm{kg})$ \\
\hline $2.5-3.5$ & 58 & $161.64 \pm 9.68^{\mathrm{a}}$ & $133.59 \pm 8.81^{\mathrm{a}}$ & $343.45 \pm 56.98^{\mathrm{a}}$ \\
$3.5-4.5$ & 94 & $176.21 \pm 6.05^{\mathrm{b}}$ & $145.52 \pm 5.31^{\mathrm{b}}$ & $452.32 \pm 30.37^{\mathrm{b}}$ \\
$4.5-5.5$ & 65 & $176.52 \pm 7.30^{\mathrm{b}}$ & $145.31 \pm 6.27^{\mathrm{b}}$ & $452.65 \pm 45.45^{\mathrm{b}}$ \\
$5.5-6.5$ & 56 & $179.18 \pm 7.08^{\mathrm{c}}$ & $144.36 \pm 6.39^{\mathrm{b}}$ & $461.32 \pm 39.62^{\mathrm{bc}}$ \\
$6.5-7.5$ & 90 & $179.38 \pm 5.58^{\mathrm{c}}$ & $144.86 \pm 5.40^{\mathrm{b}}$ & $467.81 \pm 27.90^{\mathrm{c}}$ \\
$2.5-7.5$ & 363 & $175.18 \pm 9.26$ & $143.20 \pm 7.59$ & $440.21 \pm 58.03$ \\
\hline
\end{tabular}

Means in the same column with different superscript differ significantly $(\mathrm{P}<0.05) . \mathrm{N}=$ number of cows measured; $\mathrm{CG}=$ chest girth; $\mathrm{BL}=$ body length, $\mathrm{LW}=$ live weight

Table 2. Coefficients of Correlation between Variables in Ongole Grade Cows

\begin{tabular}{cccc}
\hline $\begin{array}{c}\text { Age } \\
\text { (Years) }\end{array}$ & Variables & BL & LW \\
\hline $2.5-3.5$ & CG & 0.40 & 0.91 \\
& BL & - & 0.70 \\
$3.5-4.5$ & CG & -0.25 & 0.84 \\
& B L & - & 0.23 \\
$4.5-5.5$ & CG & 0.29 & 0.90 \\
& BL & - & 0.63 \\
$5.5-6.5$ & CG & 0.08 & 0.86 \\
& BL & - & 0.52 \\
$6.5-7.5$ & CG & 0.06 & 0.84 \\
& BL & - & 0.53 \\
$2.5-7.5$ & CG & 0.44 & 0.93 \\
& BL & - & 0.71 \\
\hline
\end{tabular}

$\mathrm{CG}=$ chest girth; $\mathrm{BL}=$ body length, $\mathrm{LW}=$ live weight; $\mathrm{BV}=$ body volume.

combination of chest girth and body length with the highest coefficients of determination $\left(\mathrm{R}^{2}\right)$ ranging from 0.93 to 0.97 for all animal age groups.

The variability as the animals' aged sharply reduced among age groups of 3.5 to 4.5 years old in all traits examined as shown in the table most probably because the matured body weight of the animal was almost fully attained on this age group. This finding was in agreement with the study of Sawanon et al. (2011) who reported that at maturity, linear body measurements were essentially a constant, thereby reflecting haritable size of the skeleton. The body conditions of the animals investigated coud be said to be good and the skeletal development was normal and consistent with the animal age.

Correlations between live weight and body linear measurements of chest girth were positive and highly significant $(\mathrm{P}<0.01)$. This implied that live weight and these linear measurements covary positively. The correlation between all pairs of linear body measurements and body live weight indicated that frame size of the animal was complementary and that the total size of the animal was a function body live weight and circumference measurements of animal body (chest girth) and body volume. Low correlation between body length and other traits was a confirmation of non-suitability of the parameters as a measure of the other parameter in the Ongole grade cattle under this study.

Based on multiple regression model, live weight changes with linear body measurements of chest girth and body length were strongly predictable with $\mathrm{R}^{2}$ values ranging at.93-0.97. The $\mathrm{R}^{2}$ values showed that 93 to 97 percents of every one kilogram change in live weight was caused by combination of the variables of chest girth and body length, while other factors not considered were responsible for between 7 and 3 percents. Unambiguously therefore, body length combined with chest girth measurements in the arranged order of suitability in multiple regression models could be used to predict the live weight of the Ongole grade cows accurately.

Determination coefficient $\left(\mathrm{R}^{2}\right)$ values of 
Table 3. Simple Regression Models for Predicting Live Weight from Chest Girth, Body Length and Body Volume in Ongole Grade

\begin{tabular}{cccrc}
\hline $\begin{array}{c}\text { Age } \\
\text { (years })\end{array}$ & $\begin{array}{c}\text { Dependent } \\
(\mathrm{Y})\end{array}$ & Independent $(\mathrm{X})$ & Regression Equation & $\mathrm{R}^{2}$ value \\
\hline $2.5-3.5$ & $\mathrm{LW}$ & $\mathrm{CG}$ & $\mathrm{Y}=-525.95024+5.37868 \mathrm{X}$ & 0.86 \\
& & $\mathrm{BL}$ & $\mathrm{Y}=-264.09880+4.54798 \mathrm{X}$ & 0.49 \\
& & $\mathrm{CG}\left(\mathrm{X}_{1}\right)+\mathrm{BL}\left(\mathrm{X}_{2}\right)$ & $\mathrm{Y}=-722.142+4.433518 \mathrm{X}_{1}+2.612289 \mathrm{X}_{2}$ & 0.97 \\
$3.5-4.5$ & $\mathrm{LW}$ & $\mathrm{CG}$ & $\mathrm{Y}=-295.17355+4.24199 \mathrm{X}$ & 0.71 \\
& & $\mathrm{BL}$ & $\mathrm{Y}=259.91192+1.32219 \mathrm{X}$ & 0.05 \\
& & $\mathrm{CG}\left(\mathrm{X}_{1}\right)+\mathrm{BL}\left(\mathrm{X}_{2}\right)$ & $\mathrm{Y}=-798.151+4.847938 \mathrm{X}_{1}+2.722636 \mathrm{X}_{2}$ & 0.93 \\
$4.5-5.5$ & $\mathrm{LW}$ & $\mathrm{CG}$ & $\mathrm{Y}=-539.70446+5.62165 \mathrm{X}$ & 0.81 \\
& & $\mathrm{BL}$ & $\mathrm{Y}=-211.33261+4.56947 \mathrm{X}$ & 0.40 \\
& & $\mathrm{CG}\left(\mathrm{X}_{1}\right)+\mathrm{BL}\left(\mathrm{X}_{2}\right)$ & $\mathrm{Y}=-832.243+4.891501 \mathrm{X}_{1}+2.900233 \mathrm{X}_{2}$ & 0.96 \\
$5.5-6.5$ & $\mathrm{LW}$ & $\mathrm{CG}$ & $\mathrm{Y}=-400.99196+4.81259 \mathrm{X}$ & 0.76 \\
& & $\mathrm{BL}$ & $\mathrm{Y}=-2.35952+3.21204 \mathrm{X}$ & 0.27 \\
& & $\mathrm{CG}\left(\mathrm{X}_{1}\right)+\mathrm{BL}\left(\mathrm{X}_{2}\right)$ & $\mathrm{Y}=-767.947+4.607500 \mathrm{X}_{1}+2.796561 \mathrm{X}_{2}$ & 0.94 \\
$6.5-7.5$ & $\mathrm{LW}$ & $\mathrm{CG}$ & $\mathrm{Y}=-288.90549+4.21856 \mathrm{X}$ & 0.71 \\
& & $\mathrm{BL}$ & $\mathrm{Y}=73.25631+2.72378 \mathrm{X}$ & 0.28 \\
& & $\mathrm{CG}\left(\mathrm{X}_{1}\right)+\mathrm{BL}\left(\mathrm{X}_{2}\right)$ & $\mathrm{Y}=-619.992+4.072457 \mathrm{X}_{1}+2.46656 \mathrm{X}_{2}$ & 0.94 \\
$2.5-7.5$ & $\mathrm{LW}$ & $\mathrm{CG}$ & $\mathrm{Y}=-580.36991+5.82584 \mathrm{X}$ & 0.83 \\
& & $\mathrm{BL}$ & $\mathrm{Y}=-335.83476+5.41813 \mathrm{X}$ & 0.50 \\
& & $\mathrm{CG}\left(\mathrm{X}_{1}\right)+\mathrm{BL}\left(\mathrm{X}_{2}\right)$ & $\mathrm{Y}=-806.410+4.79835 \mathrm{X}_{1}+2.83500 \mathrm{X}_{2}$ & 0.97 \\
\hline
\end{tabular}

$\mathrm{CG}=$ chest girth; $\mathrm{BL}=$ body length, $\mathrm{LW}=$ live weight .

multiple regressions using independent variable of chest girth and body length were higher and more consistent (0.93-0.97) compared with those of simple regression using independent variables of chest girth (0.71-0.86) and body length (0.05$0.50)$ among animal age groups. In animals of cattle breeds, Ozkaya and Bozkurt (2009) reported that chest girth was the best parameter of all prediction of body weight for Brown Swiss $\left(\mathrm{R}^{2}\right.$ $=0.91)$ and crossbred cattle $\left(\mathrm{R}^{2}=0.89\right)$ in comparison to Holstein cattle breed $\left(\mathrm{R}^{2}=0.61\right)$. In other animal of sheep, Afolayan et al. (2006) reported that the determination coefficient $\left(R^{2}\right)$ value of simple regression analysis of live body weight by chest girth was 0.88 and the $\left(\mathrm{R}^{2}\right)$ value of multiple regression analysis of live body weight by chest girth plus hip height plus height plus body length was 0.91 . This study revealed that the more the independent variables included in the model for prediction of live body weight using multiple regression, the higher the prediction accuracy of body weight by those variables. Therefore, it was found that using chest girth and body length as the independent variable were consistent with multiple regressions using animal body measurement as the independent variables and the best parameter of all animal ages for prediction of body weight in Ongole grade cows.

According to these results, the body weight estimation of Ongole grade cows using chest girth and body length as independent variables in multiple regression produced the highest accuracies of live weight prediction among all animal ages. Consequently, as one of these measurements was decreased then the animal frame size was also decreased, affecting animal live body weight. The multiple regression models that can be used when measurment is to be based 
on animal chest girth and body length are shown below:

Live weight $(\mathrm{Y}$ in $\mathrm{kg}$ unit $)=-806.410+$ 4.79835 chest girth $\left(\mathrm{X}_{1}\right.$ in $\mathrm{cm}$ unit $)+2.8350$ body length $\left(\mathrm{X}_{2}\right.$ in cm unit); with $\mathrm{R}^{2}=0.97$.

This high determination coefficient of 0.97 indicated that 97 percents of the changes of cow live weight $(\mathrm{kg})$ were due to changes of the chest girth $(\mathrm{cm})$ and body length $(\mathrm{cm})$ following the equation model with the intercept of -806.410 , chest girth coefficient $b_{1}$ of 4.79835 , and body length coefficient $b_{2}$ of 2.8350; while the rest of 3 percents of cow live weight changes were due to other unknown factors.

\section{CONCLUSIONS}

The determination coefficient $\left(\mathrm{R}^{2}\right)$ values of multiple regressions using independent variable of chest girth and body length were higher and more consistent (0.93-0.97) compared with linear regression using single independent variable of chest girth (0.71-0.86) and variable body length (0.05-0.50) among animal age groups. Therefore, multiple regression model can be recommended to predict live weight of Ongole grade cows using chest girth and body length as independent variable with their age groups ranging from 2.5 to $\geq 7.5$ years old.

\section{ACKNOWLEDGEMENT}

The financial support of the Ministry of Education and Culture, Republic of Indonesia through the Research Partnership Program is gratefully acknowledged. The authors also acknowledge J. Kuhu and his farmer group members at Tumaratas village, district of West Langowan, under development the artificial insemination service center of Minahasa regency, North Sulawesi province for their assistance in data collection.

\section{REFERENCES}

Afolayan R.A., I.A. Adetinka and C.A.M. Lakpini. 2006. The estimation of live weight from body measurements in Yankasa sheep. Czech. J. Anim. Sci. 51(8):343-348.

Bene S., B. Nagy, L. Nagy, B. Kiss, J.P. Polgar and F. Szabo. 2007. Comparison of body measurements of beef cows of different breeds. Arch. Tierz. Dummerstorf. 50(4): 363-373.
Bozkurt, Y. 2006. Prediction of body weight from body size measurements in Brown Swiss feedlot cattle fed under small-scale farming conditions. J. Appl. Anim. Res. 29:29-32.

Byrkit, D.R. 1987. Statistics Today: A Comprehensive Introduction. The Benjamin/Cummings Publishing Company, Inc. 2727 Sand Hill Road Menlo Park, California, 94025, USA.

Fajemilehin O.K.S., and A.E. Salako. 2008. Body measurement characteristics of the West African Dwarf (WAD) goat in deciduous forest zone of Southwestern Nigeria. African Journal of Biotechnology. 7(14):2521-2526.

Jimmy S., M. David, K.R. Donald and M. Dennis. 2010. Variability in body morphometric measurements and their application in predicting live body weight of Mubende and Small East African goat breeds in Uganda. Middle-East Journal of Scientific Research. 5 (2): 98-105.

Microsoft Office Excel. 2007. Software Program of Excel XP in the Computer Program Package for Users.

Ozkaya S., and Y. Bozkurt. 2009. The accuracy of prediction of body weight from body measurements in beef cattle. Archiv Tlerzucht. 52 (4): 371-377.

Puspitaningrum, D. 2009. Estimation of Live Weight Based on Body Size Dimension of Brahman Crossbred Cattle. Thesis. Faculty of Animal Husbandry, Brawijaya University, Malang.

Sawanon, S., P. Boonsaen and P. Innuruk. 2011. Body measurements of male Kamphaengsaen beef cattle as parapeters for estimation of live weight. Kasetsart J. (Nat. Sci.) 45:428-434.

Steel R.G.D., and J.H. Torrie. 1980. Principle and Procedure of Statistics: A Biometrical Approach. Second Ed. McGraw-Hill International Book Inc., Toronto.

Udeh, I., P.O. Akporhuarho and C.O. Onogbe. 2011. Phenotypic correlations among body measurements and physiological parameters in Muturu and Zebu cattle. Asian Research Publishing Network (ARPN) Journal of Agricultural and Biological Science 6 (4):14.

Ulatus Z., M. Saatci and A. Ozluturk. 2001. Prediction of body weight from body measurements in East Anatolian Red calves. J. Agri College of Ataturk University 26:6165.

Wikibooks. 2011. The Circle. http://en. 
wikibooks.org/wiki/File: CircleAnnotated, png. Opened widely at October 18, 2011.

Willeke, H. and T. Dürsch. 2002. Prediction of the body weight of Simmental heifers using heart girth measurements. Arch Tierz 45:23-28. 